\title{
Refractory Plasma Cell Myeloma
}

National Cancer Institute

\section{Source}

National Cancer Institute. Refractory Plasma Cell Myeloma. NCI Thesaurus. Code C7024.

Plasma cell myeloma that is resistant to treatment. 